NASA/TM-2009-215513

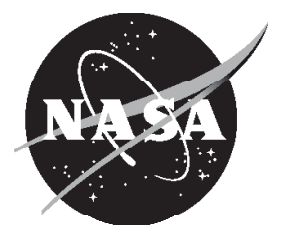

\title{
Stirling Convertor Control for a Concept Rover at NASA Glenn Research Center
}

Gina M. Blaze-Dugala

Glenn Research Center, Cleveland, Ohio 


\section{NASA STI Program . . . in Profile}

Since its founding, NASA has been dedicated to the advancement of aeronautics and space science. The NASA Scientific and Technical Information (STI) program plays a key part in helping NASA maintain this important role.

The NASA STI Program operates under the auspices of the Agency Chief Information Officer. It collects, organizes, provides for archiving, and disseminates NASA's STI. The NASA STI program provides access to the NASA Aeronautics and Space Database and its public interface, the NASA Technical Reports Server, thus providing one of the largest collections of aeronautical and space science STI in the world. Results are published in both non-NASA channels and by NASA in the NASA STI Report Series, which includes the following report types:

- TECHNICAL PUBLICATION. Reports of completed research or a major significant phase of research that present the results of NASA programs and include extensive data or theoretical analysis. Includes compilations of significant scientific and technical data and information deemed to be of continuing reference value. NASA counterpart of peer-reviewed formal professional papers but has less stringent limitations on manuscript length and extent of graphic presentations.

- TECHNICAL MEMORANDUM. Scientific and technical findings that are preliminary or of specialized interest, e.g., quick release reports, working papers, and bibliographies that contain minimal annotation. Does not contain extensive analysis.

- CONTRACTOR REPORT. Scientific and technical findings by NASA-sponsored contractors and grantees.

- CONFERENCE PUBLICATION. Collected papers from scientific and technical conferences, symposia, seminars, or other meetings sponsored or cosponsored by NASA.

- SPECIAL PUBLICATION. Scientific, technical, or historical information from NASA programs, projects, and missions, often concerned with subjects having substantial public interest.

- TECHNICAL TRANSLATION. Englishlanguage translations of foreign scientific and technical material pertinent to NASA's mission.

Specialized services also include creating custom thesauri, building customized databases, organizing and publishing research results.

For more information about the NASA STI program, see the following:

- Access the NASA STI program home page at http://www.sti.nasa.gov

- E-mail your question via the Internet to help@ sti.nasa.gov

- Fax your question to the NASA STI Help Desk at 301-621-0134

- Telephone the NASA STI Help Desk at 301-621-0390

- Write to: NASA Center for AeroSpace Information (CASI) 7115 Standard Drive Hanover, MD 21076-1320 
NASA/TM-2009-215513

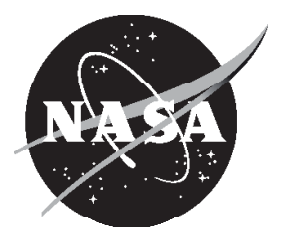

\section{Stirling Convertor Control for a Concept Rover at NASA Glenn Research Center}

Gina M. Blaze-Dugala

Glenn Research Center, Cleveland, Ohio

Prepared for the

Sixth International Energy Conversion Engineering Conference (IECEC)

sponsored by the American Institute of Aeronautics and Astronautics

Cleveland, Ohio, July 28-30, 2008

National Aeronautics and

Space Administration

Glenn Research Center

Cleveland, Ohio 44135 


\section{Acknowledgments}

The work described in this paper was performed for the Science Mission Directorate (SMD) and the Radioisotope Power System (RPS) Program, which provided funding for these projects.

Trade names and trademarks are used in this report for identification only. Their usage does not constitute an official endorsement, either expressed or implied, by the National Aeronautics and Space Administration.

Level of Review: This material has been technically reviewed by technical management.

Available from

NASA Center for Aerospace Information 7115 Standard Drive

Hanover, MD 21076-1320
National Technical Information Service 5285 Port Royal Road Springfield, VA 22161 


\title{
Stirling Convertor Control for a Concept Rover at NASA Glenn Research Center
}

\author{
Gina M. Blaze-Dugala \\ National Aeronautics and Space Administration \\ Glenn Research Center \\ Cleveland, Ohio 44135
}

\begin{abstract}
The U.S. Department of Energy (DOE), Lockheed Martin Space Systems Company (LMSSC), Sunpower Inc., and NASA Glenn Research Center (GRC) have been developing an Advanced Stirling Radioisotope Generator (ASRG) for potential use as an electric power system for space science missions. This generator would make use of the free-piston Stirling cycle to achieve higher conversion efficiency than currently used alternatives. NASA GRC initiated an experiment with an ASRG simulator to demonstrate the functionality of a Stirling convertor on a mobile application, such as a rover. The ASRG simulator made use of two Advanced Stirling Convertors to convert thermal energy from a heat source to electricity. The ASRG simulator was designed to incorporate a minimum amount of support equipment, allowing integration onto a rover powered directly by the convertors. Support equipment to provide control was designed including a linear AC regulator controller, constant power controller, and Li-ion battery charger controller. The ASRG simulator is controlled by a linear AC regulator controller. The rover is powered by both a Stirling convertor and Li-ion batteries. A constant power controller enables the Stirling convertor to maintain a constant power output when additional power is supplied by the Li-ion batteries. A Li-ion battery charger controller limits the charging current and cut off current of the batteries. This paper discusses the design, fabrication, and implementation of these three controllers.
\end{abstract}

\section{Nomenclature}

$\begin{array}{ll}\text { LMSSC } & \text { Lockheed Martin Space Systems Company } \\ \text { DOE } & \text { Department of Energy } \\ \text { ASC } & \text { Advanced Stirling Convertor } \\ \text { ASRG } & \text { Advanced Stirling Radioisotope Generator } \\ \text { NASA } & \text { National Aeronautics and Space Administration } \\ \text { GRC } & \text { Glenn Research Center } \\ \text { FTB } & \text { Frequency Test Bed } \\ \text { TDC } & \text { Technology Demonstration Convertor } \\ \text { FET } & \text { Field-Effect Transistor } \\ \text { PWM } & \text { Pulse Width Modulator } \\ \mu F & \text { Micro Farad } \\ \text { RMS } & \text { Root Mean Square } \\ \text { AH } & \text { Amp Hour } \\ \text { Hz } & \text { Hertz } \\ V_{\text {DC }} & \text { Volt, Direct Current } \\ V_{\text {AC }} & \text { Volt, Alternating Current } \\ \text { PID } & \text { Proportional-Integral-Derivative } \\ \text { IC } & \text { Integrated Circuit }\end{array}$




\section{Introduction}

An Advanced Stirling Radioisotope Generator (ASRG) simulator was designed for demonstrating Stirling power conversion outside the laboratory environment. The setup is shown in Figure 1. Two Frequency Test Bed (FTB) Stirling convertors were mounted in dual-opposed configuration. FTBs are an early version of the Advanced Stirling Convertor (ASC) for component development and testing. Fins were placed on the heat rejection zone to allow for air cooling. The outer panels of the enclosure allow observation of the convertors inside. Two fans located on the top of the enclosure draw air in from the environment and discharge into the enclosure through the top panel. The cooling fins and fans were sized for operation in ambient air temperatures up to $43{ }^{\circ} \mathrm{C}$.

Thermal energy is supplied to each hot end by an array of cartridge heaters inserted into a nickel heat collector. The hot end and regenerator sections were insulated using Kaowool (Thermal Ceramics, Inc.) ceramic blanket. The inner insulation directs the air flow exiting the cooling fins along the radial direction.

A helium management system made up of a pressure gauge, isolation valve and fill port allows for charge pressure adjustment.

The ASRG simulator system was designed to require as little support equipment as possible, with the intended application being integration onto a rover. The ASRG simulator support equipment shown in Figure 2 includes a tuning capacitor bank, control electronics, and ground support equipment. The tuning capacitor bank provides power factor correction, and is connected in series with the alternator outputs.

The control electronics include the linear AC controller, protection circuit, constant power circuit, and Li-ion battery charger. Power is supplied to the rover by one of the connectors on the front of the control electronics panel. The linear AC regulator, constant power circuit, and Li-ion battery charger will be the focus of this paper. The linear AC regulator controller parasitic loads are located on the sides of the container, and are capable of dissipating the full output power of the convertors while being air-cooled by natural convection. Any power not required by the rover is dissipated in the parasitic load. The protection circuit serves as a safety mechanism for the convertors by initiating shutdown during an over stroke of the piston.

The ground support equipment is connected to the rover via a tether. It requires a connection to a $120 \mathrm{~V}_{\mathrm{AC}}, 60 \mathrm{~Hz}$ source. It provides heater power and temperature control, cooling fan power, and centering and starting circuits. Proportional-Integral-Derivative (PID) controllers maintain the hot-end temperature set-points. If the upper temperature limit is exceeded on either heater, power is removed from the heaters by means of an alarm relay integrated into each PID controller. The centering and starting circuits are used to center the pistons in the FTB convertors before operation.

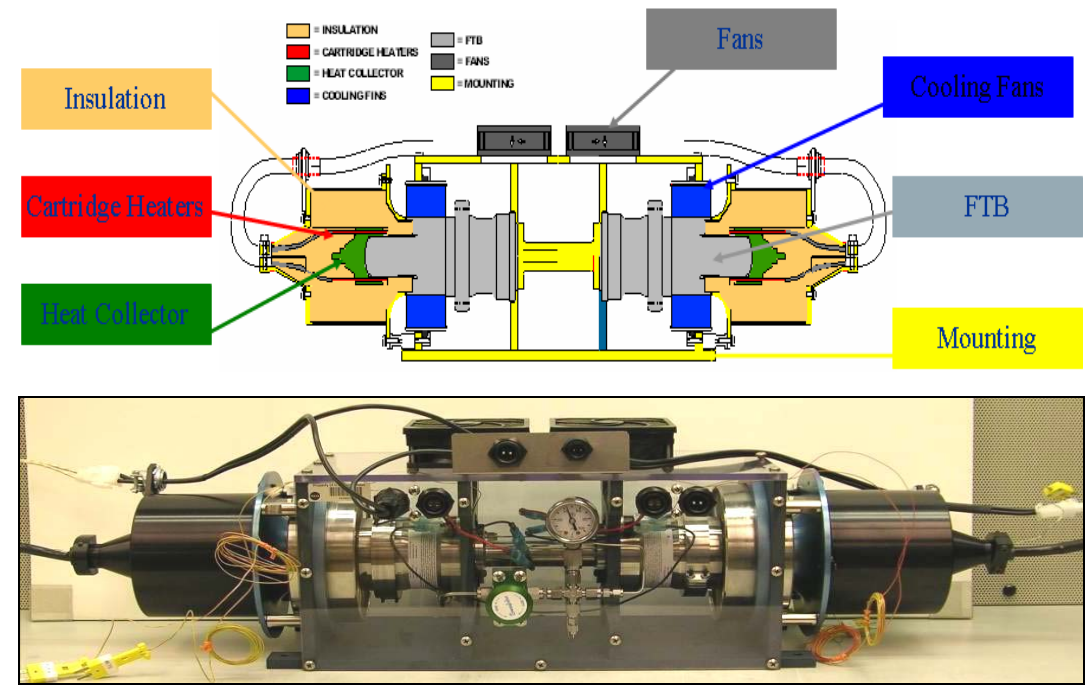

Figure 1._ASRG Simulator Setup. 


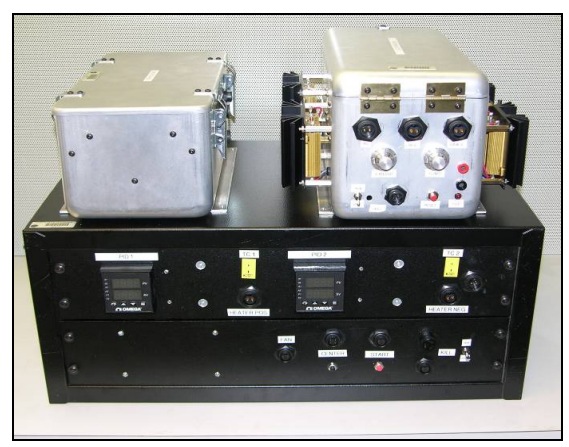

Figure 2.-Ground Support Equipment.

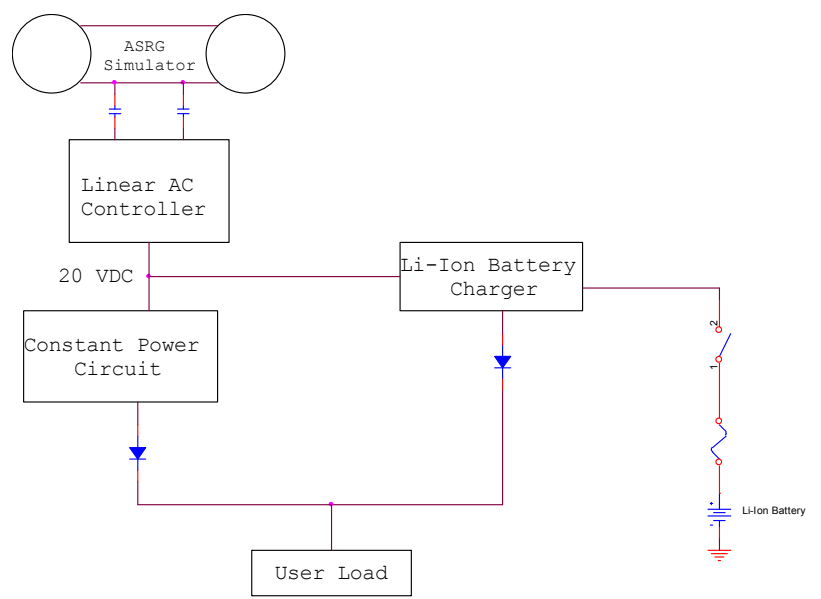

Figure 3.--Rover Power System.

Figure 3 shows a block diagram representation of the rover power system. The Li-ion batteries function to supply additional power to the rover when the rover power exceeds the power output of the Stirling convertors, $130 \mathrm{~W}$. The change in power is detected by a diode in the system that becomes forward biased when the Li-ion battery voltage is greater than the constant power circuit voltage. The constant power circuit also functions to enable the Stirling convertors to continue to maintain full power while the Li-ion batteries supply additional power.

The two FTBs in the ASRG simulator together supply $20 \mathrm{~V}_{\mathrm{DC}}, 6.5 \mathrm{~A}$, and $130 \mathrm{~W}$ at a frequency of $106 \mathrm{~Hz}$. It should be noted the design and testing of the Stirling convertor controller was performed using a $24 \mathrm{~V}_{\mathrm{DC}}$ Stirling convertor output. Specifications received at a later time verified the output voltage to be $20 \mathrm{~V}_{\mathrm{DC}}$.

Stable operation of a Stirling convertor is maintained by a controller. It regulates the alternating current produced by the linear alternator of the convertor, provides a specified output voltage, and maintains operation at a certain piston amplitude and hot-end temperature. The controller allows adjustment of the operating point; hot-end temperature or piston amplitude may be adjusted up or down. The piston amplitude is maintained by varying the load with the regulation stage of each controller. The load of the controller is sized to dissipate all the power being produced by the convertor. If the controller did not dissipate all the power, the excess would flow into the resonating piston motion, increasing amplitude, and ultimately resulting in damage to internal convertor components. Similarly, if the controller dissipated more power than that being produced, the balance would be extracted from the resonating piston motion, causing a stall of the piston.

The goal of the Stirling convertor controller task was to design and build a small, efficient, and reliable controller for use on the ASRG simulator1. Six methods of control were considered; each method was analog and used tuning capacitors for passive power factor correction. No active power factor 
correcting methods were investigated. The controller tuning capacitor provides stable convertor operation by placing the stator current in phase with piston velocity. Load current flows as a response to terminal voltage. When a tuning capacitor is used, terminal voltage is in phase with piston velocity. The phase discrepancy is caused by the inductance of the stator. It is balanced out by a capacitance to make a resistive circuit. In a resistive circuit, the voltage and current are in phase. One important consequence of this technique is the tuning capacitors ability to only cancel the effect of the alternator inductance at a single frequency. If the operating frequency deviates significantly from this value, the power factor correction will be reduced.

Originally, each control concept was designed for Technology Demonstration Convertor (TDC) operation (Ref. 2). The designs required modification to accommodate the lower alternator voltage and higher current and power output of the FTB convertors. Each controller was designed for both single convertor and dual-opposed pair operation. The circuit simulation software PSpice (Cadence Design Systems, Inc.) was used to simulate operation of the FTB convertor pair on each of the controllers by creating a model of each controller. The linear alternator was modeled as an AC voltage source using its nominal values for resistance, inductance, frequency, and output voltage. This paper discusses the controller that was selected from this process (Ref. 1).

\section{Linear AC Regulator Controller}

A schematic of the linear AC regulator controller can be viewed in Figure 4. The rectified alternator AC voltage is sensed by a voltage divider connected to an operational amplifier. The AC voltage is passed through a separate diode bridge with no energy storage capacitor that would convert it to DC. The op-amp generates a voltage proportional to the difference between the divided voltage and the set point. This output is used to drive Field Effect Transistors (FET) in their linear range, rather than discrete on-off states. The FETs connect load resistors onto the DC bus, but also dissipate power themselves. The user may change piston amplitude by adjusting the voltage divider that controls the input to the operational amplifier. The linear AC regulator was designed to have continuously variable loads, which avoid the ON/OFF behavior of a zener diode controller (Ref. 1), but retains multiple redundant load stages.

The linear AC regulator was designed to exhibit voltage stability, require few components, and have high efficiency. A disadvantage of the linear AC regulator is its use of transistors for power dissipation. The reliability of these transistors is not a major concern because the power dissipation is below the derated value.

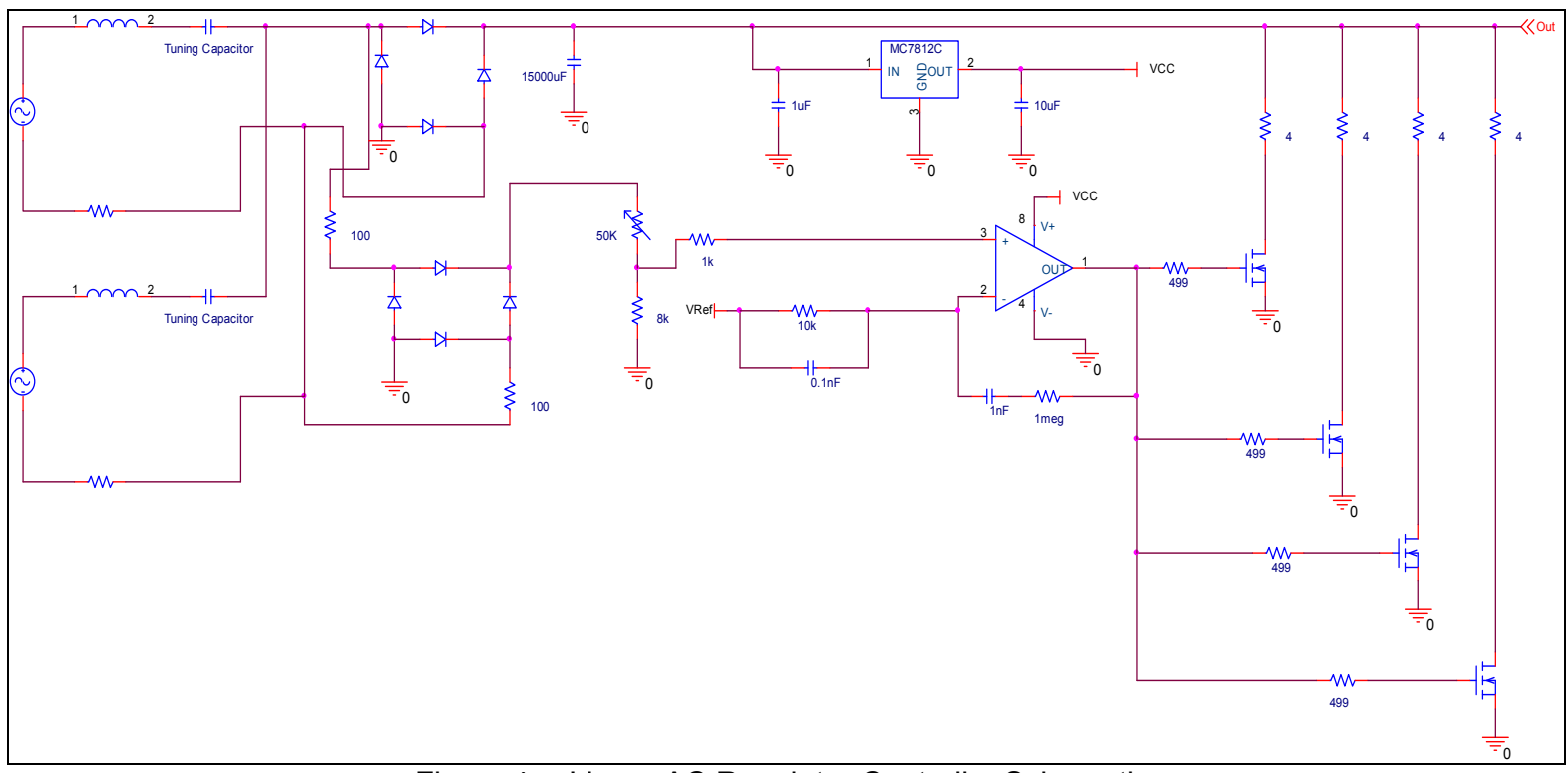

Figure 4.-Linear AC Regulator Controller Schematic. 


\section{Linear AC Regulator Bench Testing}

The purpose of the bench test was to verify the assembly of the controller and the PSpice simulations used to design the controller.

\section{Procedure}

Figure 5 shows the bench test set up of the linear AC regulator controller.

A resistor placed in series with a DC power supply produced a current through the controller. The controller voltage potentiometer was set to produce a $24 \mathrm{~V}_{\mathrm{DC}}$ output. DC voltage was used during the first test to avoid serious damage if a short was created in the circuit during assembly. The current meter on the DC power supply aided in this determination by indicating a spike in current as the input voltage increased. A significant increase in current indicated that a short was present in the circuit. Similarly, if the current increased slightly; the op-amp was regulating and assembly of the controller was successful. An AC voltage test followed this test.

A resistor placed in series with an $\mathrm{AC}$ voltage source produced a current through the controller. This test more accurately represents the operation of the controller. The input voltage, current, and power and DC output voltage were monitored with meters while the regulation stages of the op-amp were monitored on an oscilloscope.

\section{Results}

Figure 6 displays the op-amp stage data collected during the AC test. The results of this test verify the ability of the op-amp to regulate at the desired $5 \mathrm{~V}_{\mathrm{DC}}$. The limitations of the oscilloscope did not allow all four stages to be displayed simultaneously. All four stages were observed and each had the same characteristics as those displayed in Figure 6. The op-amp stages obtained from the PSpice simulation as shown in Figure 7 match the experimental results.

Figure 8 displays an op-amp regulation stage and the controller DC output voltage. The results of this test verify the ability of the controller to maintain the output voltage at $24 \mathrm{~V}_{\mathrm{DC}}$. The output voltage obtained from the PSpice simulation as shown in Figure 9 matches the experimental results.

\section{Conclusion}

The bench test verified the controller assembly and operation. In addition, it verified PSpice as an accurate tool for controller design.

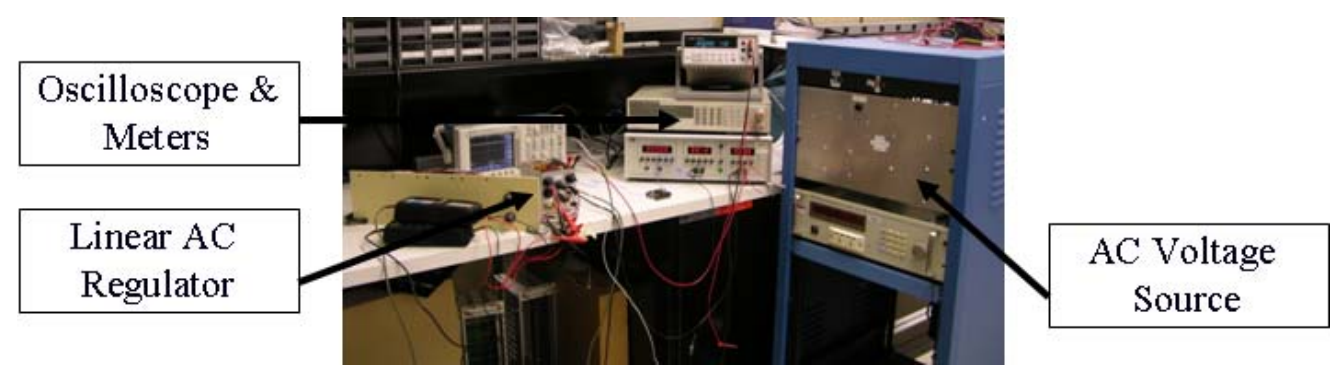

Figure 5.-Linear AC Regulator Bench Testing Setup. 


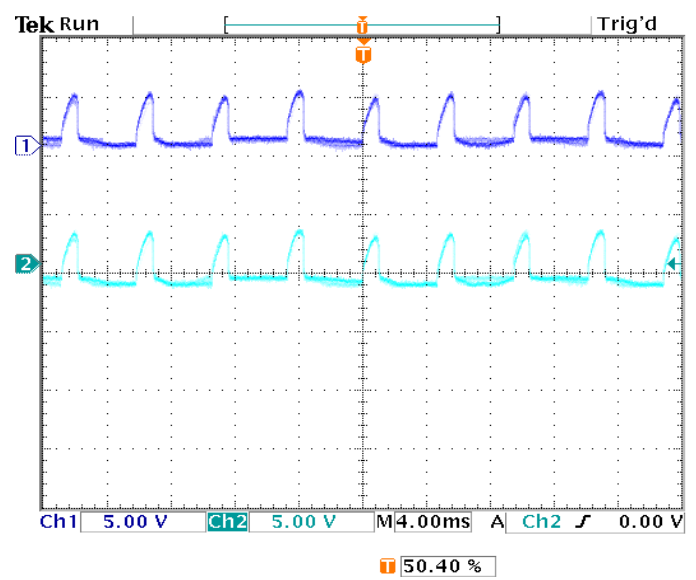

Figure 6.-Op-Amp Stages: Bench Testing.

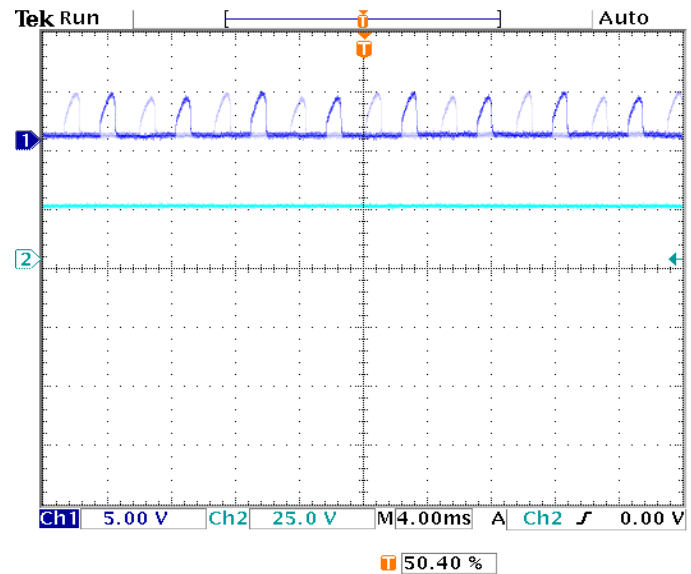

Figure 8.-DC Output Voltage: Bench Testing.

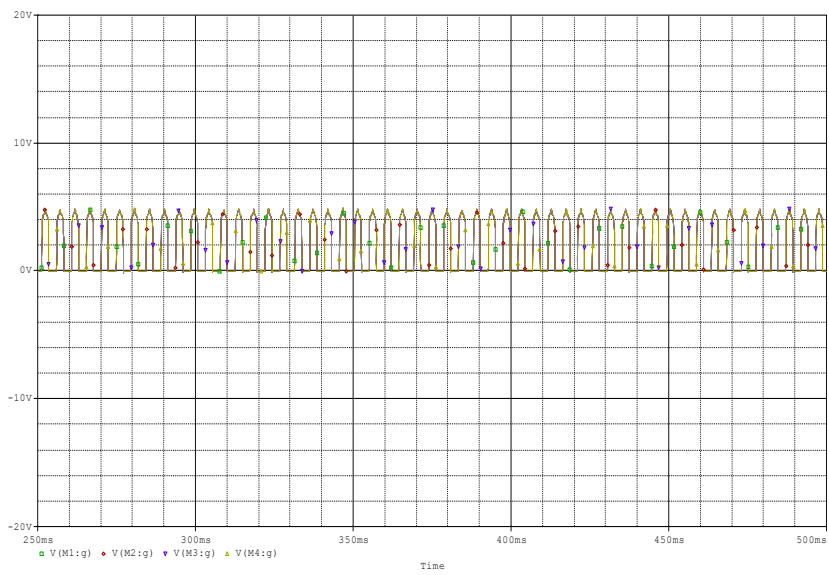

Figure 7.-Op-Amp Stages: PSpice Simulation.

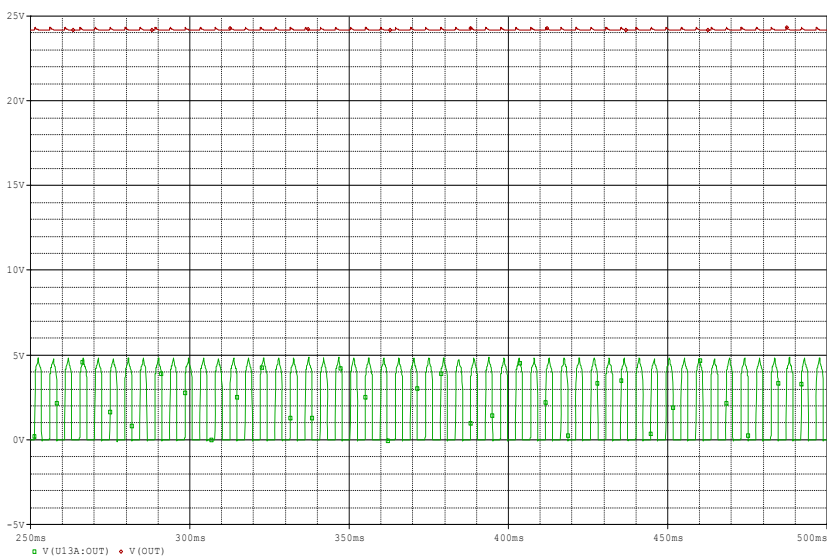

Figure 9._DC Output Voltage: PSpice Simulation.

\section{Linear AC Regulator Controlling a Pair of Convertors}

A pair of EE-35 convertors (Ref. 3) was controlled by the linear AC regulator. An EE-35 convertor is lower in power than the FTB convertors but provides the same output voltage. The purpose of controlling the EE-35 convertors with the linear AC regulator was to verify the operation of the controller and verify PSpice as an accurate tool for evaluating the performance of the controller with a Stirling convertor.

\section{Procedure}

The controller was connected to the linear alternator of the convertors. To start, the output voltage potentiometer was set to control the output voltage at $22 \mathrm{~V}_{\mathrm{DC}}$ and the hot-end temperature was increased to $300{ }^{\circ} \mathrm{C}$. The EE-35 convertors were started on the $\mathrm{AC}$ bus and transferred to the linear AC regulator controller. The potentiometer was adjusted from its original setting to produce an amplitude of $3.75 \mathrm{~mm}$. The temperature was increased to 400 and $470{ }^{\circ} \mathrm{C}$ in intervals of $5 \mathrm{~min}$ to allow for the convertors to reach steady state at each temperature. As the piston stroke increased with temperature, the potentiometer was adjusted to lower the stroke of the piston. A Yokogawa Scopecorder was used to capture waveforms of the power output, current, and DC output voltage of the EE-35 convertors. 


\section{Results}

Table I shows the alternator voltage, alternator current, power output, and DC output voltage of the convertors. The data was collected at three operating temperatures: 300,400 , and $470{ }^{\circ} \mathrm{C}$. The parameters in Table I were used to create a model in PSpice. This model represented the operation of the controller at each temperature; PSpice does not have a temperature parameter. Waveforms produced in PSpice were compared with those captured by the Yokogawa. This paper discusses the operation of the convertors at $470{ }^{\circ} \mathrm{C}$.

TABLE I.-EE-35 CONVERTOR CONTROLLED WITH THE LINEAR AC REGULATOR

\begin{tabular}{|c|c|c|c|c|}
\hline $\begin{array}{c}\text { Temperature, } \\
{ }^{\circ} \mathrm{C}\end{array}$ & $\begin{array}{c}\mathrm{V}_{\mathrm{AC}}, \\
\mathrm{V}\end{array}$ & $\begin{array}{c}\mathrm{I}, \\
\mathrm{A}\end{array}$ & $\begin{array}{c}\mathrm{P}_{\text {out }}, \\
\mathrm{W}\end{array}$ & $\begin{array}{c}\mathrm{V}_{\text {DC, }} \\
\mathrm{V}\end{array}$ \\
\hline 300 & 24.25 & 0.66 & 11.99 & 25.78 \\
\hline 400 & 24.56 & 1.16 & 22.27 & 24.12 \\
\hline 470 & 24.3 & 1.42 & 27.41 & 23.24 \\
\hline
\end{tabular}

Figures 10 and 11 represent the alternator voltage data recorded during the operation of the EE-35 convertors with the linear AC regulator.

Figure 12 represents the PSpice simulation of the alternator voltage with convertor operation at $470{ }^{\circ} \mathrm{C}$. Parameters in PSpice were adjusted to meet the power output, current input, and DC output voltage obtained during convertor operation. These parameters include the potentiometer and open circuit voltage.

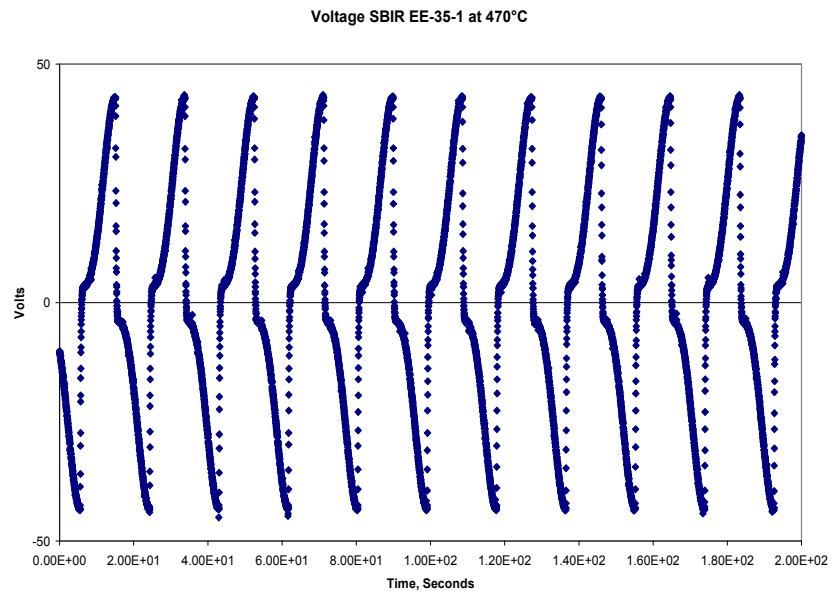

Figure 10.-EE-35-1 Alternator Voltage at $470{ }^{\circ} \mathrm{C}$.

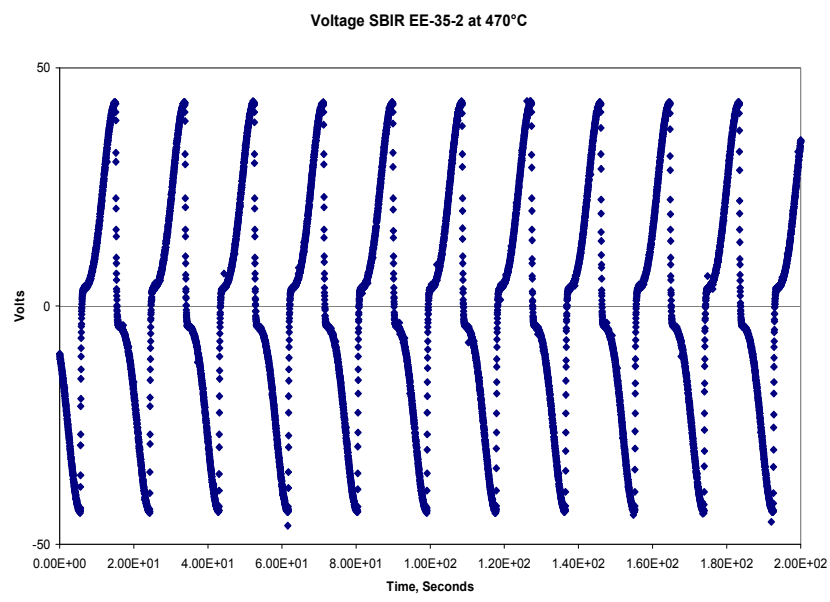

Figure 11.-EE-35-2 Alternator Voltage at $470^{\circ} \mathrm{C}$.

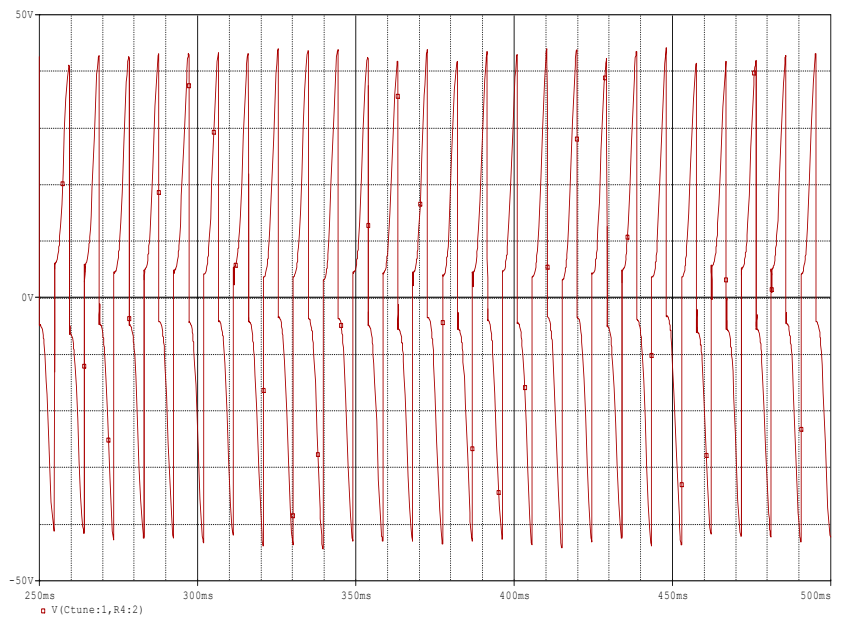

Figure 12.-PSpice Simulation of Alternator Voltage at $470{ }^{\circ} \mathrm{C}$. 


\section{Test Summary}

Operation of the EE-35 convertors with the linear AC regulator verified the ability of the linear AC regulator to control a pair of convertors. The simulation and experimental results match verifying PSpice as an accurate tool for controller design.

\section{Linear AC Regulator Efficiency Testing}

An experiment was conducted to measure controller efficiency. Power was applied to the input of the controller using an AC voltage source to simulate convertor power. The voltage and current delivered to the input were measured to calculate power input. The voltage and current delivered to the loads were also measured to calculate power output. The efficiency was calculated as the ratio between the output and input power. True RMS meters were used for all measurements. True RMS meters measure the heating potential of an applied voltage. Unlike an "average-responding" measurement, a true RMS measurement is used to determine the power dissipated in a resistor. RMS amplitude measurement is the best way to relate AC quantities to DC quantities, or other AC quantities of differing waveform shapes. The output current of the linear AC regulator is not a pure sine wave. The output current meter was capable of measuring only up to $3 \mathrm{~A}$, which limited the maximum power input to approximately $44 \mathrm{~W}$ for this experiment. At this power level, the efficiency was measured at 98.64 percent. Table II lists the calculated and experimental efficiencies. It should be noted that instrument error was not considered during experimental testing. The calculated efficiency was performed through PSpice simulation. The calculated and experimental efficiencies are at the same point in the circuit. The output current was measured as the current through the four stages. The input current was measured before the diode bridge. The circuit model predicted a controller efficiency of 95.68 percent at low power.

TABLE II.-LINEAR AC REGULATOR EFFICIENCY SUMMARY

\begin{tabular}{|l|c|c|c|}
\hline & Experimental & $\begin{array}{c}\text { Simulation, } \\
\text { low power }\end{array}$ & $\begin{array}{c}\text { Simulation, } \\
\text { full power }\end{array}$ \\
\hline Power input, W & 44.33 & 40.00 & 129.41 \\
\hline Power output, W & 43.72 & 38.27 & 123.88 \\
\hline Efficiency, Percent & 98.64 & 95.68 & 95.49 \\
\hline
\end{tabular}

\section{Linear AC Controller and ASRG Simulator Integration}

Following successful checkout on the EE-35 convertors, the linear AC controller was integrated into the ASRG simulator with the FTB convertors and electronics support. Stable operation of the FTB convertors was demonstrated up to their maximum combined power output of $130 \mathrm{~W}$.

Stability was qualitatively evaluated by observing the linear alternator voltage. While operating at full power, the alternator voltage did not deviate more than $1 \mathrm{mV}$. A photograph of the controller integrated into the support electronics can be seen in Figure 13. The controller occupies the left half of the container. The loads and their sinks are located on the outer surfaces of the container.

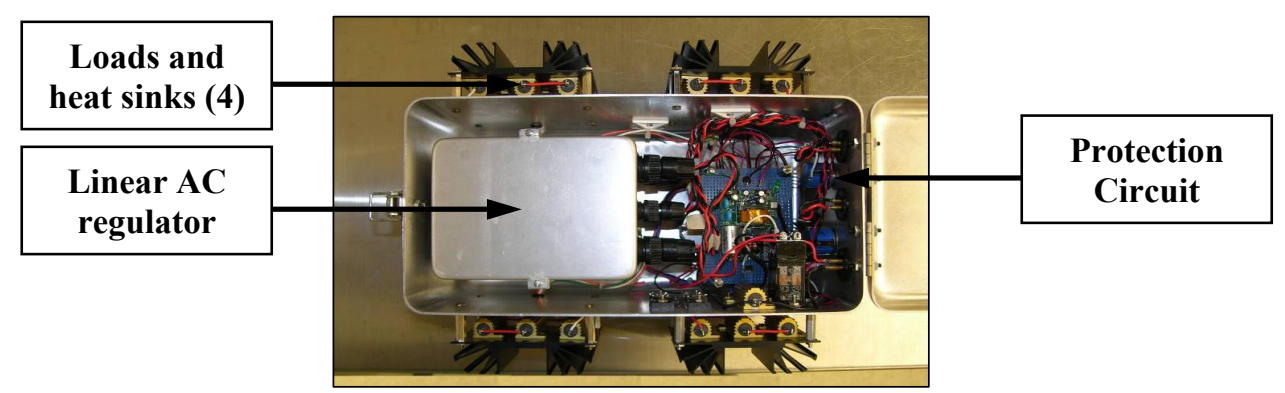

Figure 13.-Linear AC regulator controller integrated into ASRG simulator support electronics. 


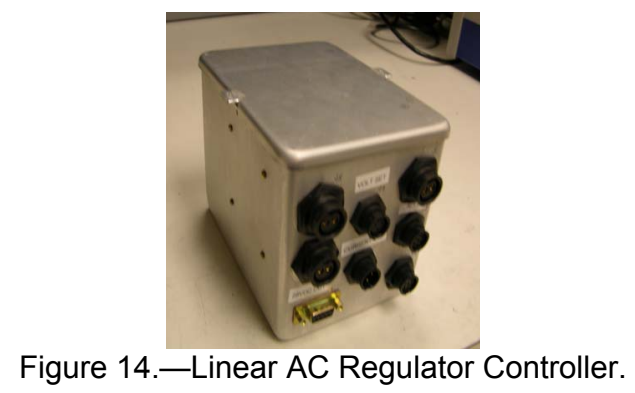

\section{Conclusion}

PSpice was the main instrument in designing the controller. The completed controller can be viewed in Figure 14. The controller was housed in a box 10.2 by 14 by $11.1 \mathrm{~cm}$ minus the load modules.

Several tests were performed on the linear AC regulator: bench, EE-35 convertor, efficiency, and ASRG simulator testing. The bench and EE-35 convertor tests verify PSpice as an accurate tool for controller design. The efficiency of the controller was measured to be 98.64 percent at low power. Following successful checkout on the EE-35 convertors, the linear AC controller was integrated into the ASRG simulator electronics support. Stable operation of the FTB convertors was demonstrated up to their maximum combined power output of $130 \mathrm{~W}$.

\section{Constant Power Circuit}

The constant power circuit maintains the Stirling convertor output to its maximum, $130 \mathrm{~W}$, while the Li-ion batteries provide additional power.

\section{DC-DC Converter}

The DC-DC converter monitors the voltage and current provided by the Stirling convertors at the output of the linear AC regulator. The TRM pin of the DC-DC converter adjusts the regulation of the DCDC converter between 24 and $28 \mathrm{~V}_{\mathrm{DC}}$ according to the current and voltage supplied by the Stirling convertors. When the rover current demands exceed the current available from the Stirling convertors, the $\mathrm{DC}-\mathrm{DC}$ converter output regulates at $28 \mathrm{~V}_{\mathrm{DC}}$. At this point, the Li-ion batteries supply additional power to the rover.

\section{Multiplier}

A multiplier is used to measure the power supplied to the load. The voltage across the load and current through the load is multiplied by means of an analog multiplier integrated circuit (IC). The multiplier provides a voltage output proportional to the power supplied to the load. The voltage input of the multiplier was scaled with a voltage divider. A current sensor detects the current supplied to the load and provides a voltage output signal proportional to the load current. This signal served as the second input to the multiplier.

The current sensor and the voltage divider were both scaled based on the following transfer function provided by the multiplier datasheet.

$$
\text { output }=\frac{(X 1-X 2)(Y 1-Y 2)}{10}
$$

$X$ is the current sensor output and $Y$ is the scaled voltage across the load. 


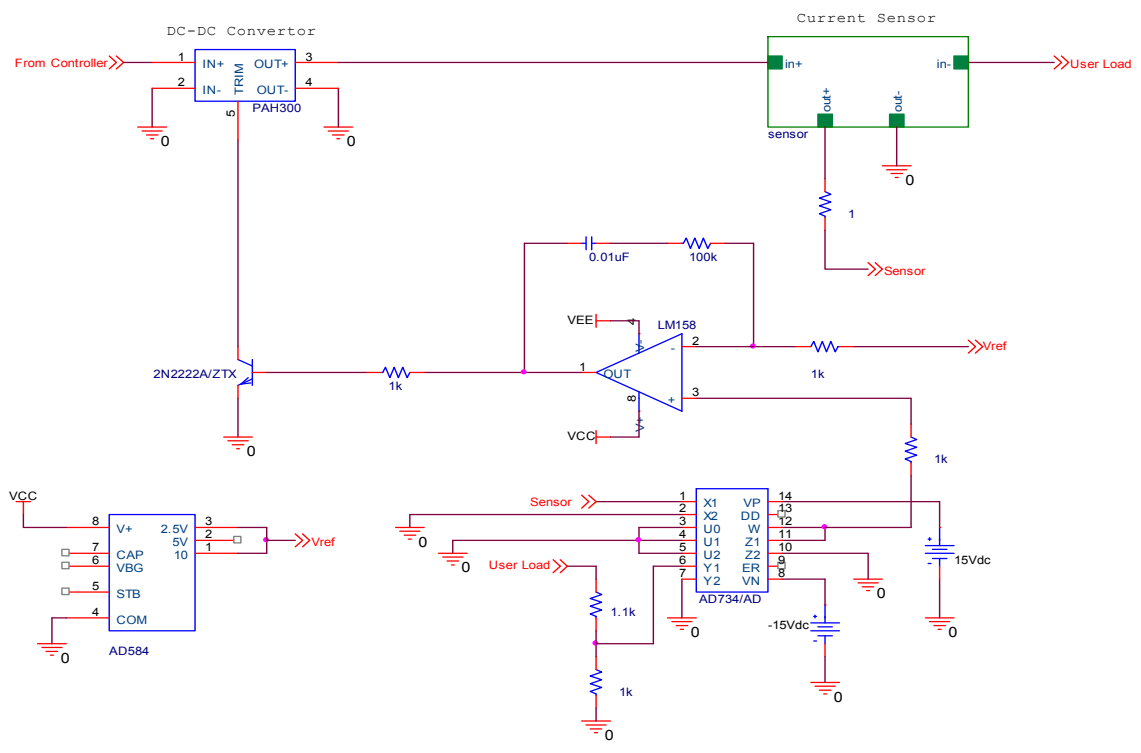

Figure 15.-Constant Power Circuit Schematic.

The voltage divider values were selected to scale the load voltage to $9.6 \mathrm{~V}_{\mathrm{DC}}$. The combined knowledge of the maximum Stirling convertor current output, $6.5 \mathrm{~A}$, and the conversion factor of the current sensor, $2.5 \mathrm{~A} / \mathrm{V}$, gave a maximum current sensor output of $2.6 \mathrm{~V}_{\mathrm{DC}}$.

$$
\text { output }=\frac{(9.6 \mathrm{~V})(2.6 \mathrm{~V})}{10 \mathrm{~V}}=2.5 \mathrm{~V}
$$

\section{Design}

A schematic of the constant power circuit can be viewed in Figure 15. The constant power circuit measures the load power by means of two analog inputs on a multiplier IC. The first input is load voltage. The second input is load current detected by a current sensor. This power signal is compared to a set point using an op-amp, which generates a voltage proportional to the difference between the two inputs. The output of the op-amp drives a transistor which activates the TRM pin of the DC-DC converter. As the power demand of the load changes, the TRM pin adjusts the output voltage of the DC-DC converter to maintain an output voltage of $28 \mathrm{~V}_{\mathrm{DC}}$ up to a maximum power load of $130 \mathrm{~W}$. When the power demands exceed $130 \mathrm{~W}, \mathrm{Li}$-ion batteries supply additional power to the rover.

\section{Battery Charger}

The battery charger charges Li-ion batteries through a constant voltage technique. The battery charger serves as a safety mechanism for the Li-ion batteries by means of a cut-off current function. The charger will use a constant voltage charge method, limit the charge current to $3.5 \mathrm{~A}$, and turn off when the current falls below 1.1 A.

\section{Lithium Ion Battery}

Li-ion cells are a high energy Li-ion chemistry that utilize a mixed metal oxide cathode material and a graphitic intercalation anode. They have an organic solvent-based electrolyte with an inorganic lithium electrolytic salt. Li-ion chemistry provides a much higher energy density and specific energy than other systems. The tolerance of a Li-ion battery is $\pm 0.05 \mathrm{~V} /$ cell. Li-ion batteries are designed to operate safely 
within their normal operating voltage but become increasingly unstable if charged to higher voltages. Overcharging can also cause the cells to heat up.

\section{Charging Technique}

A taper charge, constant voltage charge, with $\mathrm{C} / 50$ limit was used to design the charging of the Li-ion batteries. The $C$ refers to the capacity of the battery in amp hours (AH). The capacity of the battery is $55 \mathrm{AH}$. Based on the Li-ion specification sheet, the charger has a voltage limit of $4.1 \mathrm{~V} /$ cell, a maximum charge current of $\mathrm{C} / 5$, a charge cutoff of $\mathrm{C} / 50$. The battery consists of 8 cells in series for a total charger voltage limit of $32.8 \mathrm{~V}_{\mathrm{DC}}$. The charger current limit is $3.5 \mathrm{~A}$, and charger cutoff current is $1.1 \mathrm{~A}$. The current limit is based on the maximum convertor output. Full charge is reached after the voltage has reached the upper voltage threshold and the current has dropped to 1.1 A. As the battery voltage rises during the charge, the current tapers down, and the voltage rises to a float voltage level of $4.1 \mathrm{~V} / \mathrm{cell}$.

A trickle charge method was eliminated due to the Li-ion batteries inability to absorb overcharge. Trickle charge could cause plating of metallic lithium, a condition that renders the cell unstable.

\section{Design}

A schematic of the battery charger can be viewed in Figure 16. The current is detected by a current sensor. This current is compared to a set point using an op-amp, which generates a voltage proportional to the difference between the two inputs. The output of the op-amp drives a transistor which activates the TRM pin of the DC-DC converter. As the load current changes, the TRM pin adjusts the output voltage of the DC-DC converter to maintain a load current of 3.5 A. As the current draw of the Li-ion battery decreases below $3.5 \mathrm{~A}$, the transistor acts as an open circuit and drives the TRM pin by means of an adjustable resistor to a charge voltage of $32.8 \mathrm{~V}_{\mathrm{DC}}$.

The cut off circuit disconnects the Li-ion battery from system when the current decreases to $1.1 \mathrm{~A}$. The current is detected by a current sensor. This current signal is compared to a set point using an opamp, which generates a voltage proportional to the difference between the two inputs. The output of the op-amp drives a transistor which controls the activation of a normally open relay. A push button must be pressed to energize the relay. When the relay is de-energized the Li-ion battery is disconnected from the circuit.

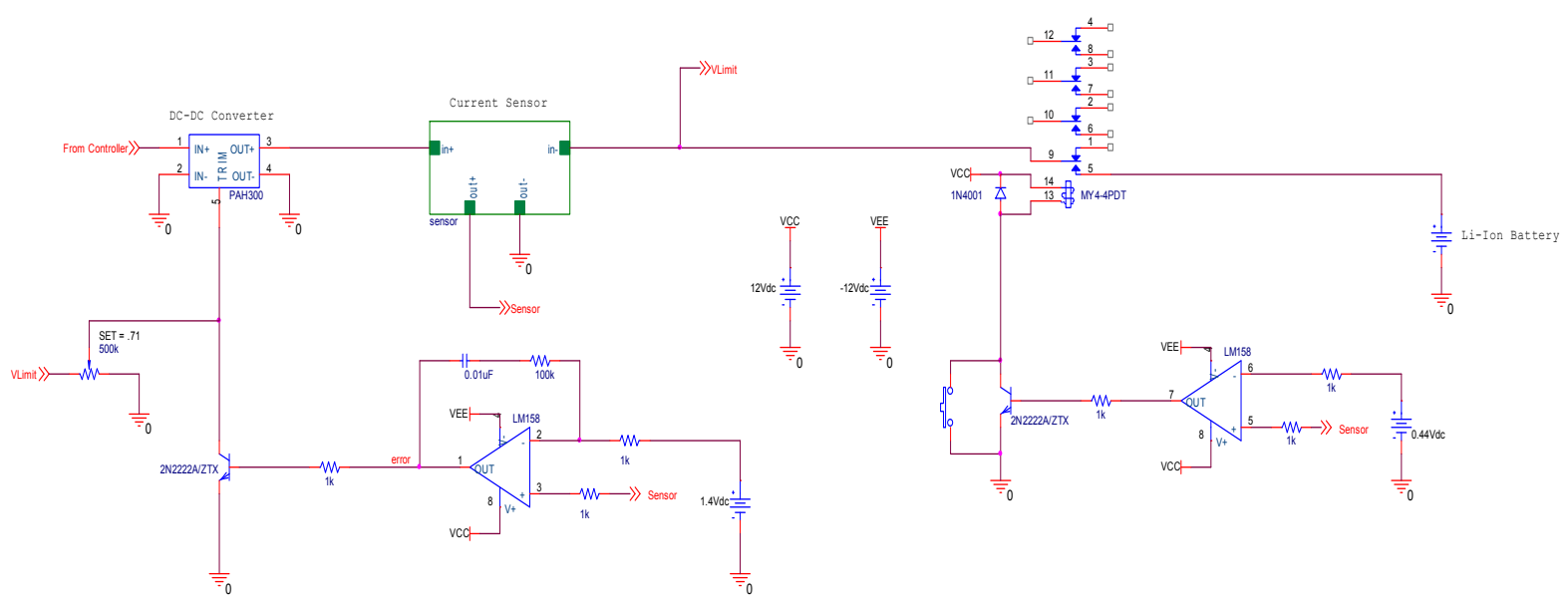

Figure 16.-Battery Charger Schematic. 


\section{System Integration Bench Test}

The purpose of the system integration bench test was to verify the operation of the constant power circuit and battery charger as a system.

\section{Procedure}

The integration bench test was set up according to Figure 3. The Li-ion battery was represented by a DC power supply. To start, the voltage reference on the constant power circuit was changed to meet different power demands. The voltage reference was set to 0.75 and $1.12 \mathrm{~V}_{\mathrm{DC}}$, which allows maximum power at 15 and $10 \Omega$, respectively. The battery voltage must be set below the maximum constant power circuit output voltage. The DC electronic load was set for resistances from 7 to $20 \Omega$. Current drawn by the DC power supply indicated additional power being supplied by the Li-ion batteries.

\section{Results}

Tables III and IV contain data for a maximum power at 15 and $10 \Omega$ loads respectively. Both tests verify the systems ability to recognize the maximum load and signal the battery to draw current.

TABLE III.-INTEGRATION TEST-MAXIMUM POWER AT A $15 \Omega$ LOAD

\begin{tabular}{|c|c|c|c|c|c|c|}
\hline $\begin{array}{c}\text { Constant power } \\
\text { current, } \\
\text { A }\end{array}$ & $\begin{array}{c}\text { Battery } \\
\text { current, } \\
\text { A }\end{array}$ & $\begin{array}{c}\text { Constant power } \\
\text { voltage, } \\
\text { V }\end{array}$ & $\begin{array}{c}\text { Vref constant } \\
\text { power, } \\
\text { V }\end{array}$ & $\begin{array}{c}\text { Load, } \\
\Omega\end{array}$ & $\begin{array}{c}\text { Battery } \\
\text { voltage, } \\
\text { V }\end{array}$ & $\begin{array}{c}\text { Vin, } \\
\text { V }\end{array}$ \\
\hline 1.3 & 0 & 27.98 & 0.75 & 20 & 25 & 19.67 \\
\hline 0.99 & 0.59 & 25.73 & 0.75 & 15 & 25 & 19.67 \\
\hline 1.86 & 0 & 25.27 & 0.75 & 15 & 20 & 19.67 \\
\hline
\end{tabular}

\begin{tabular}{|c|c|c|c|c|c|c|}
\hline $\begin{array}{l}\text { Constant power } \\
\text { current, } \\
\text { A }\end{array}$ & $\begin{array}{c}\text { Battery } \\
\text { current, } \\
\text { A }\end{array}$ & $\begin{array}{l}\text { Constant power } \\
\text { voltage, } \\
\text { V }\end{array}$ & $\begin{array}{l}\text { Vref constant } \\
\text { power, } \\
\text { V }\end{array}$ & $\begin{array}{c}\text { Load, } \\
\Omega\end{array}$ & $\begin{array}{c}\text { Battery } \\
\text { voltage, } \\
\text { V }\end{array}$ & $\begin{array}{c}\text { Vin, } \\
\text { V }\end{array}$ \\
\hline 2.09 & 0 & 27.97 & 1.12 & 12 & 26.529 & 19.67 \\
\hline 0.91 & 1.5 & 26.57 & 1.12 & 10 & 26.529 & 19.67 \\
\hline 0.93 & 2.04 & 26.47 & 1.12 & 8 & 26.529 & 19.67 \\
\hline 0.98 & 2.37 & 26.44 & 1.12 & 7 & 26.529 & 19.67 \\
\hline
\end{tabular}

Current is drawn from the battery if two conditions are met; the battery voltage is greater than the constant power circuit voltage and the load is at maximum power. A data point in Table III verifies these two conditions along with the functionality of the diode to remain reverse biased until the battery voltage is greater than the constant power circuit voltage.

Table IV data indicates that if maximum load is reached and continues to increase, the constant power circuit current and voltage remain the same. This data validates the operation of the constant power circuit to maintain the Stirling convertor output while the Li-ion batteries supply additional power.

\section{Test Summary}

The integration of the constant power circuit and the battery charger was successful. The Li-ion batteries, represented by a DC power supply, supplied additional power when the linear AC regulator reached its maximum power output. It also demonstrated that the diodes in the circuit operated properly; the batteries did not supply power unless the battery voltage was greater than the constant power circuit output voltage. 


\section{Conclusion}

This paper discussed the design of support equipment for the ASRG simulator. The ASRG simulator and support equipment were designed for use on a concept rover. The linear AC regulator controlled the FTB convertors in the ASRG simulator. Bench testing, integration testing, and efficiency testing were performed on the controller.

A constant power circuit was designed to maintain the power output of the Stirling convertors at $130 \mathrm{~W}$ while Li-ion batteries supply additional power to the load. The constant power circuit was designed and simulated in PSpice and bench tested to verify the design.

The battery charger charges Li-ion batteries through a constant voltage technique. The battery charger serves as a safety mechanism for the Li-ion batteries by means of a cut-off current function. The charger will use a constant voltage charge method, limit the charge current to $3.5 \mathrm{~A}$, and turn off when the current falls below 1.1 A. The battery charger was designed and simulated in PSpice and bench tested to verify the design.

The constant power circuit and battery charger were integrated as a system and tested. The test verified the systems capability to combine the functions of each circuit; the constant power circuits' ability to maintain Stirling convertor power at $130 \mathrm{~W}$ while the Li-ion batteries supply additional power.

\section{References}

1. Salvatore Oriti, Gina Blaze, "Advanced Stirling Convertor Testing at NASA Glenn Research Center," International Energy Conversion Engineering Conference, St. Louis, 2007.

2. Jeffrey Schreiber, "Developmental Considerations on the Free-Piston Stirling Convertor for Use in Space," International Energy Conversion Engineering Conference, San Diego, 2006.

3. Gina Blaze, "Stirling Convertor Control for a Lunar Concept Rover," Master's Thesis at Cleveland State University, Cleveland, 2007. 


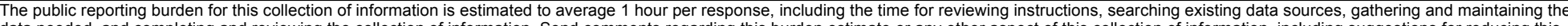

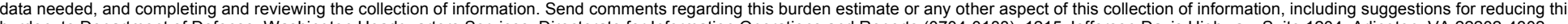

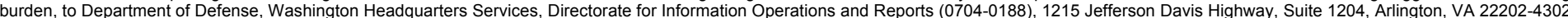

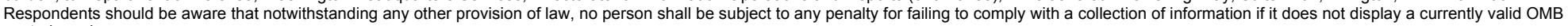
control number.

PLEASE DO NOT RETURN YOUR FORM TO THE ABOVE ADDRESS.

\section{REPORT DATE $(D D-M M-Y Y Y Y)$ \\ 2. REPORT TYPE \\ 3. DATES COVERED (From - To)}

01-03-2009

\section{TITLE AND SUBTITLE}

Technical Memorandum

Stirling Convertor Control for a Concept Rover at NASA Glenn Research Center

\section{AUTHOR(S)}

Blaze-Dugala, Gina, M.

\section{5a. CONTRACT NUMBER}

5b. GRANT NUMBER

5c. PROGRAM ELEMENT NUMBER

\section{5d. PROJECT NUMBER}

5e. TASK NUMBER

5f. WORK UNIT NUMBER

WBS 138494.04.01.01

8. PERFORMING ORGANIZATION

REPORT NUMBER

E-16812

National Aeronautics and Space Administration

John H. Glenn Research Center at Lewis Field

Cleveland, Ohio 44135-3191

9. SPONSORING/MONITORING AGENCY NAME(S) AND ADDRESS(ES)

National Aeronautics and Space Administration

Washington, DC 20546-0001

10. SPONSORING/MONITORS
ACRONYM(S)
NASA; AIAA
11. SPONSORING/MONITORING
REPORT NUMBER
NASA/TM-2009-215513

\section{DISTRIBUTION/AVAILABILITY STATEMENT}

Unclassified-Unlimited

Subject Category: 20

Available electronically at http://gltrs.grc.nasa.gov

This publication is available from the NASA Center for AeroSpace Information, 301-621-0390

\section{SUPPLEMENTARY NOTES}

\section{ABSTRACT}

The U.S. Department of Energy (DOE), Lockheed Martin Space Systems Company (LMSSC), Sunpower Inc., and NASA Glenn Research Center (GRC) have been developing an Advanced Stirling Radioisotope Generator (ASRG) for potential use as an electric power system for space science missions. This generator would make use of the free-piston Stirling cycle to achieve higher conversion efficiency than currently used alternatives. NASA GRC initiated an experiment with an ASRG simulator to demonstrate the functionality of a Stirling convertor on a mobile application, such as a rover. The ASRG simulator made use of two Advanced Stirling Convertors to convert thermal energy from a heat source to electricity. The ASRG simulator was designed to incorporate a minimum amount of support equipment, allowing integration onto a rover powered directly by the convertors. Support equipment to provide control was designed including a linear $\mathrm{AC}$ regulator controller, constant power controller, and Li-ion battery charger controller. The ASRG simulator is controlled by a linear AC regulator controller. The rover is powered by both a Stirling convertor and Li-ion batteries. A constant power controller enables the Stirling convertor to maintain a constant power output when additional power is supplied by the Li-ion batteries. A Li-ion battery charger controller limits the charging current and cut off current of the batteries. This paper discusses the design, fabrication, and implementation of these three controllers.

15. SUBJECT TERMS

Controllers; Stirling cycle; Radioisotope generator; Convertors

\begin{tabular}{|c|c|c|c|}
\hline \multicolumn{3}{|c|}{ 16. SECURITY CLASSIFICATION OF: } & \multirow{2}{*}{$\begin{array}{l}\text { 17. LIMITATION OF } \\
\text { ABSTRACT } \\
\text { UU }\end{array}$} \\
\hline $\begin{array}{l}\text { a. REPORT } \\
\mathrm{U}\end{array}$ & $\begin{array}{l}\text { b. ABSTRACT } \\
U\end{array}$ & $\begin{array}{l}\text { c. THIS } \\
\text { PAGE } \\
\text { U }\end{array}$ & \\
\hline
\end{tabular}

18. NUMBER
OF
PAGES
19

19a. NAME OF RESPONSIBLE PERSON STI Help Desk (email:help@sti.nasa.gov) 19b. TELEPHONE NUMBER (include area code) 301-621-0390 

